\title{
$\underline{\mathbf{P}-23}$
}

\section{Evaluation of Antioxidant Chemiluminescence of Isolated Compounds from the Bark of Shorea Bracteolate}

\author{
Norhazana Nor Izan ${ }^{1}$, Norizan Ahmat ${ }^{1, *}$, Yana Maolana Syah ${ }^{2}$, Yoshiaki Takaya ${ }^{3}$, Zurina Shameeri ${ }^{1}$, \\ Wan Zuraida Wan Mohd Zain ${ }^{1}$ \\ ${ }^{I}$ Faculty of Applied Sciences, Universiti TeknologiMARA (UiTM), 40450 Shah Alam, Selangor; ${ }^{2}$ Department of \\ Chemistry, Institut Teknologi Bandung, Jalan Ganesha 10, Bandung 40132, Indonesia; ${ }^{3}$ Faculty of Pharmacy, Meijo \\ University, Nagoya; E-mail: noriz118@salam.uitm.edu.my
}

Shorea species is the largest subfamily of Dipterocarpaceae and are the source of resveratrol oligomers (oligostilbene), sesquiterpenes and triterpenes. Shorea bracteolate also called white meranti is locally known as "Meranti Pa' ang" and is widely distributed in Sumatera, Peninsular Malaysia, Indonesia and Singapura. The tree is up to $50 \mathrm{~m}$ in height and the timber is light hardwood. The study was undertaken to extract and isolate the chemical constituents from the stembark of Shorea species namely Shorea bracteolate and to elucidate the structures of the chemical constituents isolated by using modern spectroscopic methods and evaluated their antioxidant chemiluminescence. The structure of the isolated compounds was determined based on analysis of spectroscopic data, including NMR, UV, IR and comparison with previous reported studies. Five oligomers resveratrol were isolated from the acetone extract of stem bark Shorea bracteolate namely hemsleyanol E (1), vaticanol A (2), ampelopsin H (3), hopephenol (4) and hopeaphenol A (5). The result showed that in antioxidant chemiluminescence, compound (3) and (2) showed moderate activity $\left(\mathrm{IC}_{50}: 6.7 \mu \mathrm{mol} / \mathrm{ml}\right.$ and $\left.10.7 \mu \mathrm{mol} / \mathrm{ml}\right)$ as compared to ascorbic acid $\left(\mathrm{IC}_{50}: 1.71 \mu \mathrm{mol} / \mathrm{ml}\right)$. However, compound (1), (2) and (3) displayed low activity $\mathrm{IC}_{50}: 17.1 \mu \mathrm{mol} / \mathrm{ml}, 15.8 \mu \mathrm{mol} / \mathrm{ml}$ and $14.3 \mu \mathrm{mol} / \mathrm{ml}$.

Keywords: Dipterocarpacea, Shorea bracteolate, oligomers resveratrol, antioxidant chemiluminescence, ampelopsin $\mathrm{H}$. 